\title{
ACTIVE METHODS OF TRAINING STAFF FOR THE FORMATION OF CORPORATE CULTURE OF PRIVATELY OWNED HIGHER EDUCATION INSTITUTIONS
}

\author{
Nataliia Nakonechna ${ }^{1}$ \\ ${ }^{1}$ Ph.D. (Psychology), Associate Professor of the Psychology department, KROK University, Kyiv, Ukraine, e- \\ mail: natalyn@krok.edu.ua,ORCID: https://orcid.org/0000-0001-6236-9549
}

In the modern system of education of Ukraine, along with the state owned institutions, there are higher privately owned education establishments. This fact may be explained with the priority development of the institution of private property, which determines the change of relations in the educational sphere.

Corporate culture of higher education institutions is characterized by distinctness, operating in a competitive environment and requirements of the modern labour market, which forms a fundamentally new type of relationship between education entities, both within a corporation and outside it; it is characterized by a unique combination of private interests and traditional pedagogical values.

New conditions for functioning of higher education institutions, in particular, the intensification of the process of entering the European educational area, necessitate changes in the organization and content of the educational and upbringing process, which with no proper adjustment of corporate culture can lead to the so-called "cultural gap", and the latter may result in a loss of values and achievements reached by the education institution.

Currently in the study of organizational (corporate) culture and its development, some thematic areas of analysis of this phenomenon have already been formed and clearly defined, and some scientific schools have been established. This is, first of all, the typology of organizational culture of Ch. Handy [30], E. Shane [31], K. Cameron, R. Quinn [10] A. Radugin, K. Radugin, [23] classification of organizational and psychological research methods of L. Teplova [24], establishing the levels of development of organizational culture of I. Ladanov [15], and, especially in relation to the formation and development of organizational culture of education institutions, i.e. fundamental and scientific and methodical works of domestic scientists S. Maksymenko [16], G. Ball [1], L. Karamushka [11], N. Zavatska [9].

A training form of education was chosen as the main method of psychological training of managers for the development of corporate culture, because, as it is shown by the analysis of the work of specialists in the field of organizational and economic psychology $[2 ; 6$; thirteen; $17 ; 19 ; 29 ; 33]$ it stimulates the group activity, combines and synthesizes information into new knowledge, forms an emotional attitude to it, increases the level of motivation to acquire knowledge and skills, forms the group's 
ability to think collectively and make decisions, and most importantly, it promotes practical check and consolidation of knowledge [19].

The main purpose of the training is to teach specific skills. The training allows its participants not only to hear a teacher's opinion or look at tables and diagrams, but also to practically apply the acquired knowledge, turning it into skills. Therefore, the training form of work is used more and more increasingly in modern education systems, especially in adult education and retraining [19].

The works of famous Ukrainian and foreign scientists in the field of organizational and economic psychology, as well as specialists in training activities made up the theoretical and methodological basis of our training program.

The works that reveal the content, methods and forms of active psychological training of organizations' staff considerable contributed to the development of the training program (O. Bondarchuk [3], O. Vynoslavska [5], O. Yevtykhov [7], L. Karamushka [13], S. Maksymenko [17], K. Milutina [19], E. Mykhailova [18], Fopel [30], T. Yatsenko [33] and others.

An important role for the development of the training was played by the works that reveal psychological features of education organizations, in particular of universities in modern conditions (O. Bondarchuk [3], N. Zavatska [8; 9], L. Karamushka [12], N. Kolominsky [14] and others).

The purpose of the training program is psychological training of managers of privately owned education establishments for further participation of the former in the development of corporate culture of universities.

Tasks of the training program for managers are as follows:

1. assimilation of knowledge about the content, structure of the function of corporate culture in privately owned universities;

2. mastering methods of diagnostics and analysis of psychological features of corporate culture of privately owned education institutions and the factors influencing its formation;

3. formation of skills for developing corporate culture of privately owned education institutions.

According to its structure, the training program consisted of three training sessions (training session I "Organizational culture as an important factor in ensuring the efficiency and development of the organization"; training session II "Corporate culture of privately owned education institutions"; training session III "Development of corporate culture of privately owned education institutions"). Each of the above, in its turn, contained the introductory and concluding parts and two modules (Table 1). In addition, the program provided for self-study in a form of homework assignments.

The essential meaningful elements of the organizational (corporate) culture and the functions which these elements carry out are considered under each structural 
component of the training program-session modules, i.e. value-based and worldview functions as well as regulative and behavioural ones. The main attention is paid to the development of the educational and upbringing process as the core of corporate culture of a university.

\section{Table 1. General Structure of the Training Program "Corporate Culture of} Privately Owned Universities"

\begin{tabular}{|c|c|c|}
\hline Structural parts & Modules & Hours \\
\hline \multirow{4}{*}{$\begin{array}{l}\text { Training session I } \\
\text { "Organizational culture as an } \\
\text { important factor in ensuring } \\
\text { efficiency and development of an } \\
\text { organization" }\end{array}$} & Introduction to the training session & \multirow{4}{*}{8} \\
\hline & $\begin{array}{l}\text { Module 1: "Organizational culture: terms, } \\
\text { components, main functions" }\end{array}$ & \\
\hline & $\begin{array}{l}\text { Module 2: "Types and kinds of the } \\
\text { organizational culture. The organizational culture } \\
\text { of an education organization. Corporate culture } \\
\text { as one of the types of the organizational culture } \\
\text { of an education institution" }\end{array}$ & \\
\hline & Summing up the training session & \\
\hline \multirow{4}{*}{$\begin{array}{l}\text { Training session II } \\
\text { "Corporate culture of privately } \\
\text { owned education institutions" }\end{array}$} & Introduction to the training session & \multirow{4}{*}{8} \\
\hline & $\begin{array}{l}\text { Module 3: "Features of the corporate culture of } \\
\text { privately owned universities" }\end{array}$ & \\
\hline & $\begin{array}{l}\text { Module 4: "Factors in the formation of corporate } \\
\text { culture of privately owned universities" }\end{array}$ & \\
\hline & Summing up the training session & \\
\hline \multirow{4}{*}{$\begin{array}{l}\text { Training session III } \\
\text { "Development of corporate culture } \\
\text { of privately owned education } \\
\text { institutions" }\end{array}$} & Introduction to the training session & \multirow{4}{*}{8} \\
\hline & $\begin{array}{l}\text { Module 5: "Directions and ways of development } \\
\text { of the corporate culture of privately owned } \\
\text { universities" }\end{array}$ & \\
\hline & $\begin{array}{l}\text { Module 6: "Innovation management as an } \\
\text { important factor in the development of an } \\
\text { effective corporate culture of privately owned } \\
\text { universities" }\end{array}$ & \\
\hline & $\begin{array}{l}\text { Summing up the training session and the training } \\
\text { as a whole }\end{array}$ & \\
\hline \multicolumn{2}{|l|}{ Self-study } & 8 \\
\hline \multicolumn{2}{|l|}{ In total } & 32 \\
\hline
\end{tabular}

Source: the author's development

Each training session is tailored for one working day once a week with duration of 8 hours. 8 hours ( 4 hours each) are allotted for homework assignments in the break between classes (self-study). In total, the training program is designed for 32 hours.

The developed training program is based on the basic principles of training work, selected by us on the basis of analysis of references $[6 ; 7 ; 13 ; 11-13 ; 17 ; 18$; $19 ; 21 ; 22 ; 30]$. Among the main ones we can mention the following, namely voluntariness, equality, activity, confidentiality, restriction of discussion of events, statements, emphasis, personification of statements, and avoidance of direct assessments of a person, trustful and open communication. 
Voluntariness. The training group members and its facilitator participate in the work of the group consciously and they are governed by their own free will. Sometimes it is overstepped when it concerns the trainer: "You are a psychologist of our organization. Do something immediately to motivate work." But more often, other problems related to compliance with this principle arise among the participants, namely: the company administration forces them to attend the training (often in their spare time) and acquire some skills that seem useful to the manager. It is clear that in such cases not only the principle of voluntariness is violated, but also effectiveness of the training becomes unacceptably low. Therefore, when concluding agreements with customers, it is necessary to take into account practical ways of implementing this principle.

Equality. All participants have the same rights and responsibilities. Problems with compliance with this principle arise in corporate trainings, when the participants have different professional status and transfer this system of relationships into the training environment. In personal growth groups, there is also an informal structure that breaks up the initial equality. The selection of a homogeneous group and reflection on how the distribution of roles affects equality can prevent such problems.

Activity distinguishes the training work from other forms of learning, including lectures. The trainer should create relevant conditions for manifestation of the group's activity, and the participants should direct their efforts to gain practical, emotional and sensuous experience. The activity of the group depends on some factors, including the level of interest in the problem, the level of knowledge, background experience in conducting trainings, relationships in the group and between the group and the facilitator. The activity of the group has natural fluctuations during a day.

At the same time, an activity is a relatively independent organizational and psychological phenomenon. There are three levels of activity depending on the degree of independence:

- reproductive (direct reproduction of a textbook material or a story of the teacher-trainer);

- search as a transformative reproduction that stimulates one's own cognitive activity;

- creative activity, which involves identifying new aspects in the material under study.

Confidentiality of everything that happens in the group is an important principle of a social and psychological training, which is a necessary condition for creating an atmosphere of psychological security and self-disclosure. Everything that happens during classes is not disclosed outside the group. The participants are not afraid that what they were talking about may become widely known. 
First of all, the trainer does not have a real opportunity to ensure compliance with this rule in the communication of the participants outside the group. In addition, it is difficult to determine what information perceived during the training is confidential: the trainer should write a report, the participants should support the acquired skills; the communication often does not end when the training is over, but continues at work. It has become the norm for practicing trainers to use a different name during team trainings, as well as to agree on the confidentiality of any other person's experience that becomes known during the training [19].

Confidentiality in this case is a phenomenon that should be considered in terms of the ratio of the individual against the collective. Everything positive that is achieved in the corporate culture by an individual should be in manifested in an impersonalized way, in a generalized form in the collective, by synthesizing into the new, constructive, which is one of the conditions for development of corporate culture.

The principle of limiting the discussion of events only to the training ("here and now") and the personification of statements. The participants of training groups often tend to wander from the main topic, tend to have general conversations, considerations, which are not connected with the subject of the training. This principle directs the participants of the training that the subject of their analysis be constantly the processes that take place in the group at a particular time.

The principle of emphasis promotes deep reflection of the participants, teaches the participants to focus their attention on themselves, their thoughts, feelings, develops their self-analysis skills.

The principle of personification of statements. Its key point boils down to the fact that the participants of the training should focus on the processes of selfknowledge, self-analysis and reflection. Even the assessment of behaviour should be done through the expression of their own feelings and experiences. Refusal from impersonal speech forms helps people hide their position and avoid responsibility in everyday communication. If in other fields of psychology it can be regarded as a waiver of self-responsibility, in the study of corporate culture such categorical conclusions can hardly be made, because, on the contrary, this situation may indicate that a person really reflects a point of view of a certain group, which focuses on its already existing and established subculture.

In an education institution, due to the specifics of cross-sectional departments that reflect different areas of knowledge and different styles of professional corporate conduct (e.g., legal deontology, legal ethics, professional code of ethics of an economist), such an assessment may be completely reasonable.

The principle of accentuation of speaking up about feelings. According to this principle, the emotional side of communication should be well and fully expressed by 
the participants of the training; they are encouraged to focus on states and manifestations (of their own and those of their partners) and, when giving feedback, if possible, they should use the language that reflects that state. An example of this is the following statement: "Your manner of speaking in high tones irritates me." A more indirect form of expressing feelings is formed by the language of images, associations and metaphors, which are used in the training on both verbal and nonverbal levels. Indirect speech is usually less traumatic and less harsh, which is important if you need to deliver not very pleasant information.

Avoidance of direct assessments of a person. They need to be replaced by descriptions of one's own emotional states, as the likelihood of not accepting negative feedback increases when the latter is purely evaluative. It is not desirable to use the statement like: "I do not like you". Instead, you need to say: "I do not like your behaviour" and so on. It is known that negative information activates the protective mechanisms of an individual and is often rejected.

The principle of trustful and open communication is one of the fundamental elements of the training. Developing a climate full of trust is a complex process. The simplest first step to the practical creation of the climate of trust may be as follows: the facilitator proposes to adopt a single form of addressing "you", which psychologically equates all members of the group and adds some element of intimacy and trust into the relationship between the group members and the manager. Everyone realizes the level of openness to which s/he is ready, depending on their own peculiarities and the general level of trust in the group.

An important role in training is given to interactive techniques.

Interactive techniques (derived from the English word "interaction"), as defined by L.M. Karamushki are techniques that provide active interaction between managers and staff of organizations (or separately between representatives of each of these categories) in conditions of trainings and seminars aimed at preparing managers and staff to address current management and professional tasks [13].

According to the classification of L.M. Karamushka [13], interactive techniques can be divided into two groups (depending on the functions they perform in the organization of training):

organizational and guiding (organizational and preparatory techniques, study of expectations of the participants regarding trainings and seminars, joint development of group work rules, "icebreakers" (forms that "split" the ice of tension that arises from time to time during classes), creation of small groups (or pairs, etc.);

conceptual and sense-bearing (mini-lectures; filling in worksheets; "brainstorming"; group discussions and discussions with "open end"; situation analysis; role-playing games; drawing; defence of projects, etc.). 
In accordance with the developed training program "Corporate culture of privately owned universities" the content of the training is developed by combining the main structural elements (i.e., training sessions, which, in their turn, consist of an introduction, two modules and a conclusion), and interactive techniques used to present each of the structural elements.

The results of experimental implementation and features of the training program were reflected in the molding stage of the study, during which the effectiveness of the training program was determined.

To this end, based on the approaches of Ukrainian scientists [26; 27], we have developed two groups of criteria for evaluating the effectiveness of the training program, i.e. basic and additional.

The main criteria include the following:

1. The maturity level of the organizational culture of a university. The criterion was measured using the method of "Assessment of the level of organizational culture" of I. Ladanov [104]", which diagnoses the maturity level of organizational culture in general and based on the main components including work, communication, management, motivation and morale.

2. The maturity level of types of the organizational culture of a university (of real and aimed at one). We investigated this criterion using the method of "Assessment of organizational culture" of K. Cameron and R. Quinn" [10], according to which organizational cultures is broken into four types: the clan culture, the adhocratic culture, the hierarchical culture, the market culture.

3. The assessment level of the types of organizational culture of a university. We researched this criterion using the method of "Determining a type of organizational culture" by Charles Handy, according to which organizational cultures is broken into four types: the power culture, the task culture, the role culture, the person culture [31].

These methods were used to perform assessments, which were made at the beginning of the molding experiment and after its completion in the control and experimental groups.

Then the obtained data were subjected to mathematical processing using the statistical software package SPSS (version 13).

In order to identify statistically significant dynamics between the results of the first and second assessments in the control and experimental groups, we used the Gcriterion of signs, which is based on counting the number of positive and negative differences in one sample between recurred measurements $[4 ; 20 ; 21]$.

According to our approach, additional criteria include indicators of evaluation of the effectiveness of the training participants, which were measured using a questionnaire: 
1) assessment of the need and general motivation in terms of their participation in the training for the experimental group participants;

2) analysis of expectations of the experimental group participants;

3) meeting expectations of the experimental group's participants;

4) evaluation of the effectiveness of the training (in the breakdown of the content, forms and methods of activities and general evaluation) made by the experimental group participants.

Let us analyse the obtained results of generalized data of experimental implementation of the training program "Corporate culture of a privately owned university" according to the main criteria in more detailed way.

First of all, we will analyse the results obtained regarding the maturity level of organizational culture of a university.

The data indicate that statistically significant differences between $(p<0.05 ; p$ $<0.01)$ the results of the first and second assessments were recorded in the experimental group as a result of the molding experiment. Namely, such changes took place under such components of organizational culture as "communication" and "motivation and morality". It should be noted that the general indicator of the maturity level of organizational culture and the component "work" also showed some positive changes, but only at the level of trends (Table 2).

When it comes to the control group, here, as we see in Fig. 1, no statistically significant differences have been found.

Thus, in our opinion, we can say that the training helped to increase the level of evaluation of organizational culture, in particular under such "more psychological" components as "communication" and "motivation and morality".

Let us move on to the analysis of the obtained results according to the second criterion, i.e. the maturity level of the types of real and aimed at organizational culture of a university (the clan culture, the adhocratic culture, the hierarchical culture, the market culture).

As it can be seen on Figures 1 and 2, the results of the survey in the experimental group showed a statistically significant relationship $(p<0.01)$ between the first and second assessments under the clan type of organizational culture. Moreover, this trend is observed both in the assessment of the real organizational culture and the aimed at one. We will remind that the clan organizational culture is characterized by high cohesion of the team, a positive moral climate, presence of common goals, a large number of traditions and so on. Managers in such companies are perceived as educators. Such organizations emphasize self-improvement of the individual; success here is accompanied by a good attitude to consumers and care for people. 
Table 2. Comparative analysis of the maturity level of organizational culture components of a university before and after the molding experiment in the control and experimental groups

(shown in \% of the total number of respondents)

\begin{tabular}{|c|c|c|c|c|}
\hline $\begin{array}{c}\text { The maturity level } \\
\text { of the organizational } \\
\text { culture components }\end{array}$ & $\begin{array}{c}\text { Cefore the molding } \\
\text { experiment }\end{array}$ & $\begin{array}{c}\text { After the molding } \\
\text { experiment }\end{array}$ & $\begin{array}{c}\text { Before the molding } \\
\text { experiment }\end{array}$ & $\begin{array}{c}\text { After the molding } \\
\text { experiment }\end{array}$ \\
\hline \multicolumn{5}{|c|}{ General indicator } \\
\hline Low & 0,0 & 0,0 & 0,0 & 0,0 \\
\hline Medium & 16,0 & 16,0 & 12,0 & 4,0 \\
\hline High & 76,0 & 72,0 & 84,0 & 92,0 \\
\hline Very high & 8,0 & 12,0 & 4,0 & 4,0 \\
\hline \multicolumn{5}{|c|}{ Work } \\
\hline Low & 8,0 & 8,0 & 12,0 & 12,0 \\
\hline Medium & 28,0 & 36,0 & 36,0 & 36,0 \\
\hline High & 64,0 & 56,0 & 52,0 \\
\hline Low & 12,0 & 8,0 & $16,0^{*}$ & $0,0^{*}$ \\
\hline Medium & 32,0 & 36,0 & $44,0^{*}$ & $28,0^{*}$ \\
\hline High & 56,0 & 56,0 & $40,0^{*}$ & $72,0^{*}$ \\
\hline \multicolumn{5}{|c|}{ Management } \\
\hline Low & 12,0 & 12,0 & 8,0 & 4,0 \\
\hline Medium & 60,0 & 56,0 & 32,0 \\
\hline High & 28,0 & 32,0 & 36,0 & 0,0 \\
\hline Low & 8,0 & 4,0 & $32,0^{* *}$ \\
\hline Medium & 68,0 & 64,0 & $68,0^{* *}$ \\
\hline High & 24,0 & 32,0 & $12,0^{* *}$ & $64,0^{* *}$ \\
\hline
\end{tabular}

* $\mathrm{p}<0,05 ; * * \mathrm{p}<0,01$

Source: the author's development



Fig. 1. The maturity level of the types of real and aimed at organizational culture of a university before the molding experiment $\left(1^{\text {st }}\right.$ assessment) and after the molding experiment $\left(2^{\text {nd }}\right.$ assessment $)$ : the results of the survey in the control

Source: the author's development group 


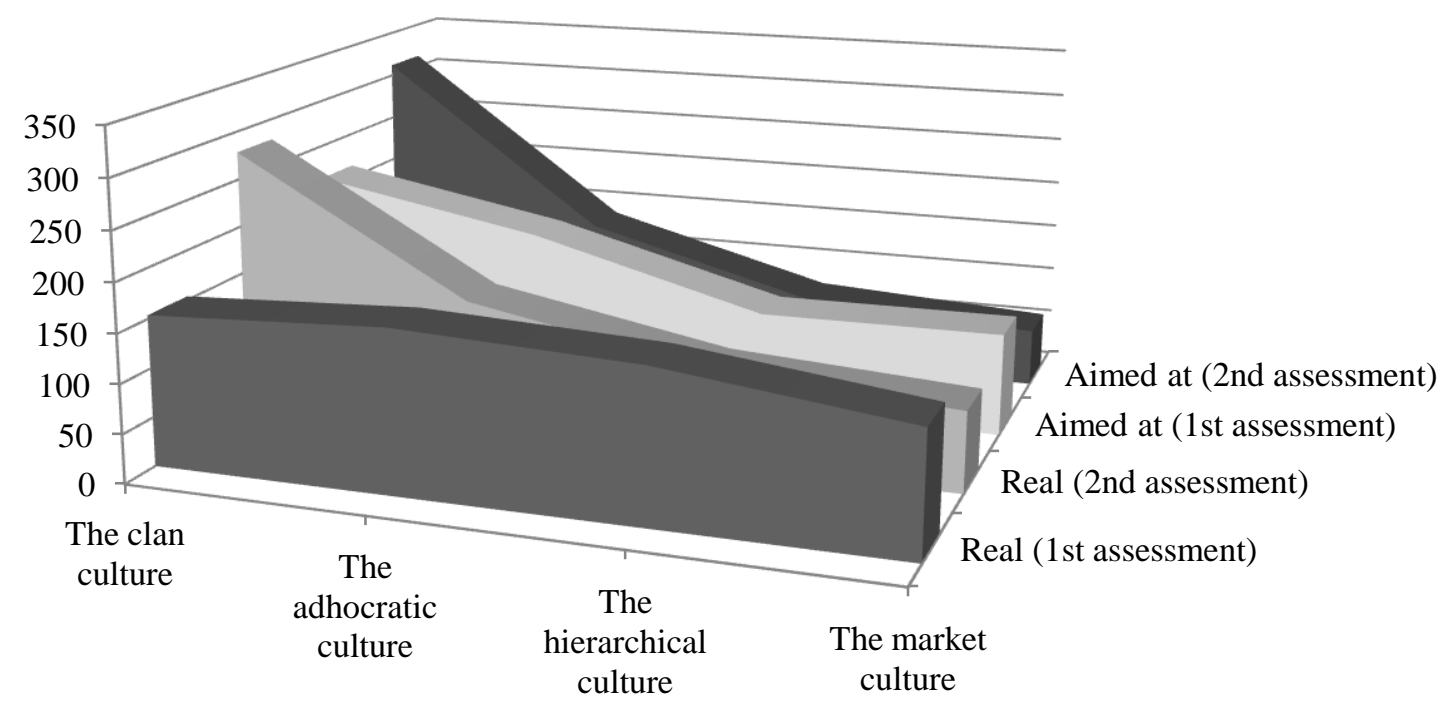

Fig. 2. The maturity level of the types of real and aimed at organizational culture of a university before the molding experiment $\left(1^{\text {st }}\right.$ assessment) and after the molding experiment ( $2^{\text {nd }}$ assessment): the results of the survey in the experimental group

Source: the author's development

As we see in Table 3, the average values for the assessment of the clan organizational culture increased from 153.8 to 278.6. Thus, in our opinion, we can conclude that the university managers have more appreciated the importance of such indicators in the organizational culture as cohesion, dedication/loyalty, care for people, self-realization and so on.

When it comes to the control group, no statistically significant differences have been found between the first and second assessments.

Table 3. Comparative analysis of the maturity level of organizational culture of a university before and after the molding experiment in the control and experimental groups (average values)

\begin{tabular}{|c|c|c|c|c|}
\hline \multirow{2}{*}{$\begin{array}{c}\text { Types of } \\
\text { organizational } \\
\text { culture }\end{array}$} & \multicolumn{2}{|c|}{ Control group } & \multicolumn{2}{|c|}{ Experimental group } \\
\hline & $\begin{array}{c}\text { Before the molding } \\
\text { experiment }\end{array}$ & $\begin{array}{l}\text { After the molding } \\
\text { experiment }\end{array}$ & $\begin{array}{l}\text { Before the molding } \\
\text { experiment }\end{array}$ & $\begin{array}{l}\text { After the molding } \\
\text { experiment }\end{array}$ \\
\hline The clan culture & 159,2 & 178,4 & $153,8^{* *}$ & $278,6^{* *}$ \\
\hline $\begin{array}{l}\text { The adhocratic } \\
\text { culture }\end{array}$ & 164,1 & 158,5 & 165,6 & 142,9 \\
\hline $\begin{array}{l}\text { The hierarchical } \\
\text { culture }\end{array}$ & 135,0 & 141,1 & 155 & 98,04 \\
\hline $\begin{array}{l}\text { The market } \\
\text { culture }\end{array}$ & 135,4 & 127,9 & 125,4 & 82,68 \\
\hline
\end{tabular}

Source: the author's development 
Next, we will analyse the results of empirical research under the third criterion: the level of evaluation of the types of organizational culture of a university (the power culture, the task culture, the role culture, the person culture).

The obtained data from the empirical research showed that there is a statistically significant relationship between the results of the first and second assessments according to such type of organizational culture as "the person culture" $(\mathrm{p}<0.001)$ (see Fig. 3-4).

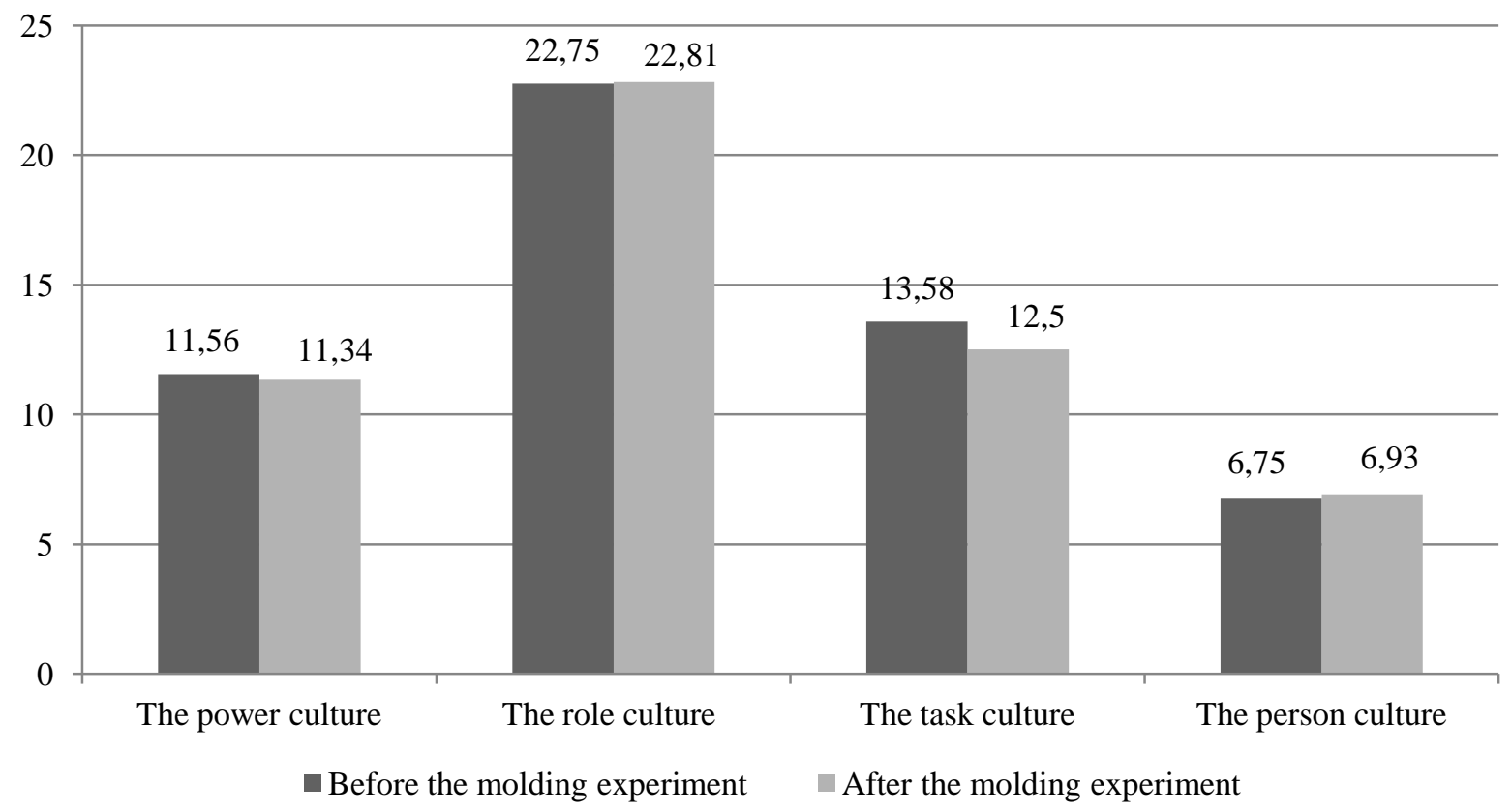

Fig. 3. The maturity level of organizational culture of a university before and Source: the author's development after the molding experiment in the control group

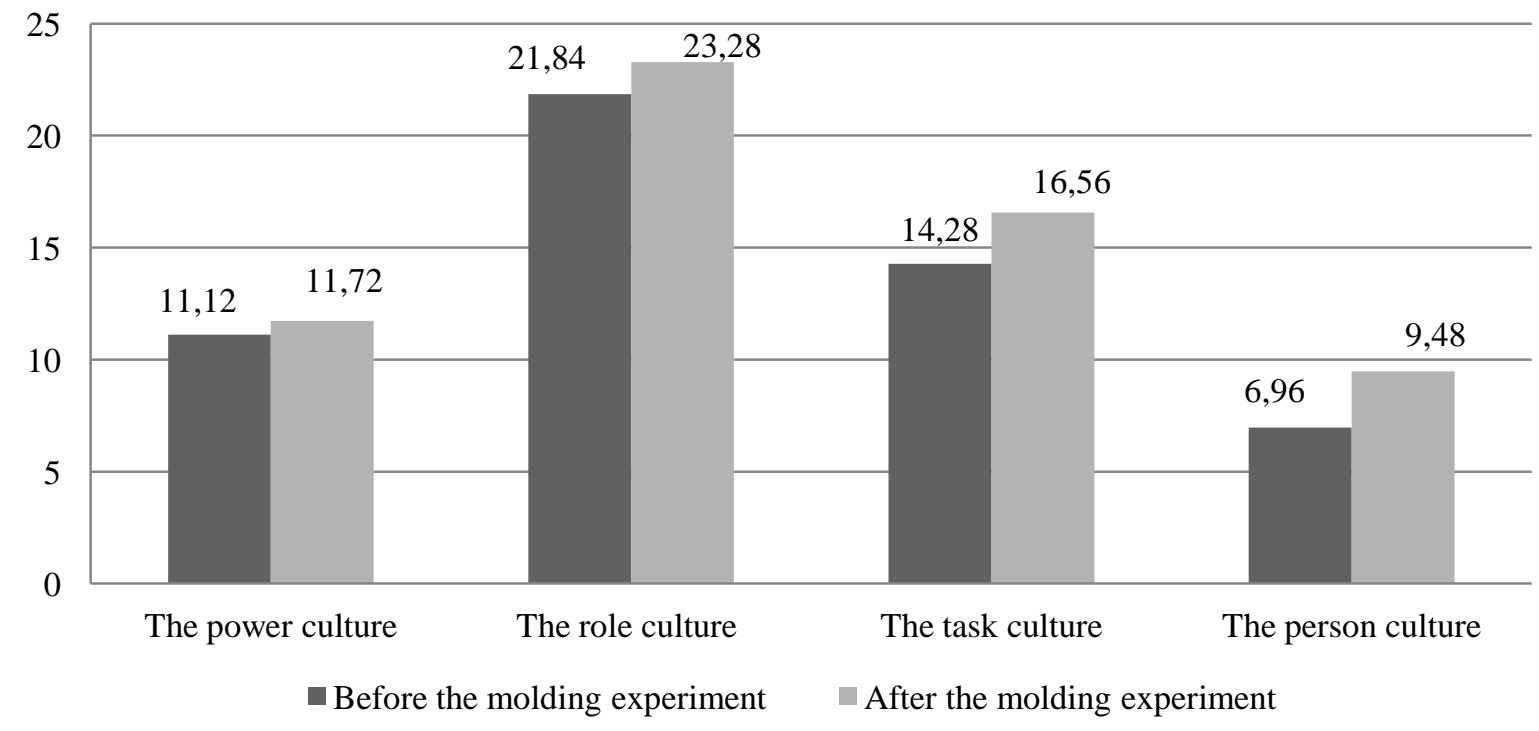

Fig. 4. The maturity level of organizational culture of a university before and after the molding experiment in the experimental group

Source: the author's development 
In other words, the average values of assessment by the type "the person culture" increased from 6.96 to 9.48 . There have been no statistically significant differences in other types of organizational culture (the power culture, the role culture and the task culture) (Table 4).

\section{Table 4. Comparative analysis of the maturity level of types of organizational} culture of a university before and after the molding experiment in the control and experimental groups (M)

\begin{tabular}{|c|c|c|c|c|}
\hline \multirow{2}{*}{$\begin{array}{c}\text { Types of } \\
\text { organizational } \\
\text { culture }\end{array}$} & \multicolumn{2}{|c|}{ Control group } & \multicolumn{2}{|c|}{ Experimental group } \\
\hline & $\begin{array}{c}\text { Before the molding } \\
\text { experiment }\end{array}$ & $\begin{array}{l}\text { After the molding } \\
\text { experiment }\end{array}$ & $\begin{array}{l}\text { Before the molding } \\
\text { experiment }\end{array}$ & $\begin{array}{c}\text { After the molding } \\
\text { experiment }\end{array}$ \\
\hline The power culture & 11,56 & 11,34 & 11,12 & 11,72 \\
\hline The role culture & 22,75 & 22,81 & 21,84 & 23,28 \\
\hline The task culture & 13,58 & 12,5 & 14,28 & 16,56 \\
\hline $\begin{array}{l}\text { The person } \\
\text { culture }\end{array}$ & 6,75 & 6,93 & $6,96 * * *$ & $9,48 * * *$ \\
\hline
\end{tabular}

$* * * p<0,001$

Source: the author's development

No statistically significant differences between the first and second assessments have been found in the control group.

Summarizing the results of the molding experiment under the main criteria, it can be stated that there are clear significant changes in the managers' assessment of organizational culture of a university and its psychological components, namely, the maturity level of components of "communication" and "motivation and morality" has increased, the maturity level of the clan type and the person type of organizational culture has increased. That is, it can be said that the conducted molding experiment contributed to understanding of the importance of psychological factors in organizational culture and management of a university as a whole. And this was the main goal of our training.

Let us move on to the analysis of empirical data of the molding experiment according to additional criteria.

The first criterion "assessment of the need and general motivation of the experimental group participants to take part in the training" was assessed using the following questions: "Do you need trainings on the development of corporate culture of a privately owned university?", "Why do I participate in the training?".

The results of the survey of the experimental group participants about the need for training on the development of corporate culture of a privately owned university showed that $40 \%$ of university managers are clearly aware of this need, and another $28 \%$ have such a need but they are a little less aware of it. In other words, we can say that almost two thirds of the respondents (17 people) need trainings on the development of corporate culture of a privately owned university. At the same time, a 
quarter of employees have a little need for training or none at all. As a result we can conclude that the facilitator has a task not only to meet needs of the participants, but also to intensify this need for those participants who do not have it.

As for the specific motives for participation in the training, the results of the survey indicate that $60 \%$ of university managers participate in the training driven by a high level of interest in the problem of organizational culture (Fig. 5).

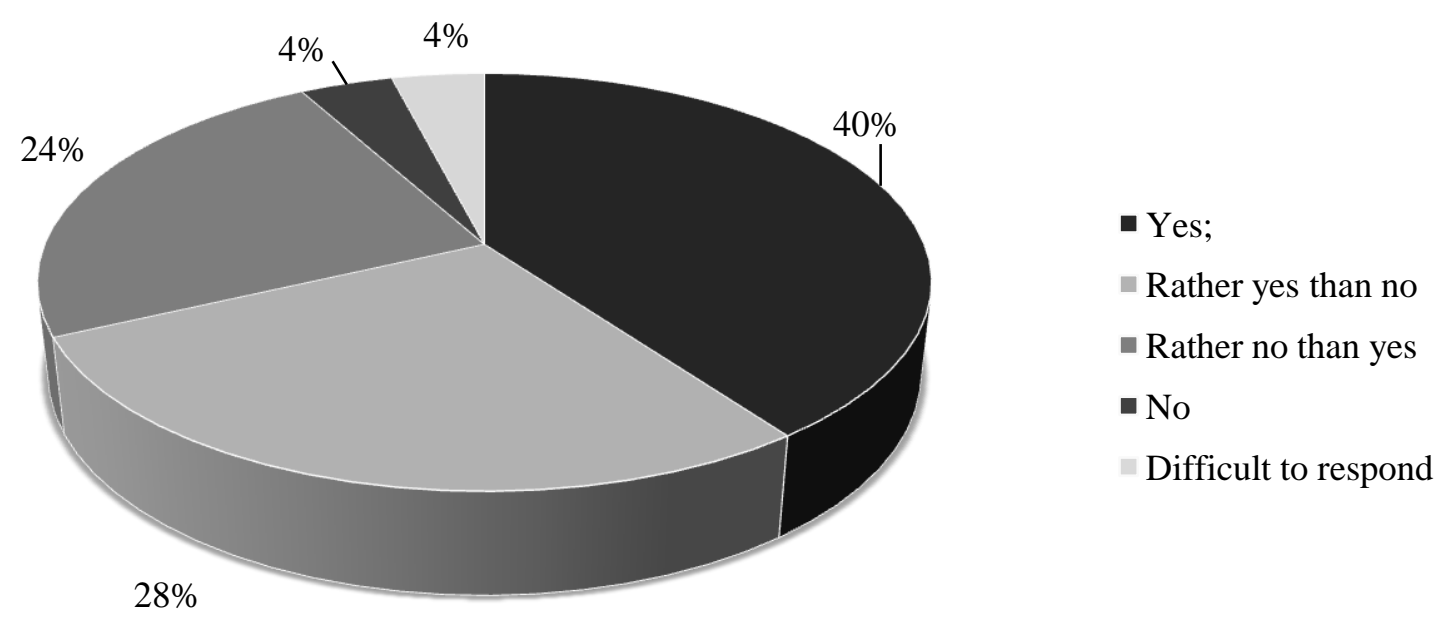

Fig. 5. The presence of experimental group participants' needs in trainings on the development of corporate culture of a privately owned university (in \% of the total number of respondents)

Source: the author's development

For example, the participants gave the following answers: "I believe that the development of the university's corporate culture plays a key role in ensuring effective operation"; "I am interested in new methods and diagnostics of corporate culture"; "Participation in the training will expand my understanding of the peculiarities of organizational culture", etc.

In addition, 20\% of the respondents indicated the need for professional and personal development, and 15\% specified their social and communication needs (building relationships, improving communication, etc.) as the main motives for participation in the training.

In our opinion, we can say that in order to ensure its high efficiency, the training should help meet not only the needs related to the content of the stated problem, but also a number of other social and psychological needs of the individual.

The second criterion "analysis of expectations of the experimental group participants" was evaluated using the following questions: "What knowledge do I want to get from the training?" and "What specific practical skills and abilities do I want to master?". These questions were open, so the participants had an opportunity 
to freely express their expectations. The answers we received were analysed using the content analysis, which allowed us to obtain the following results.

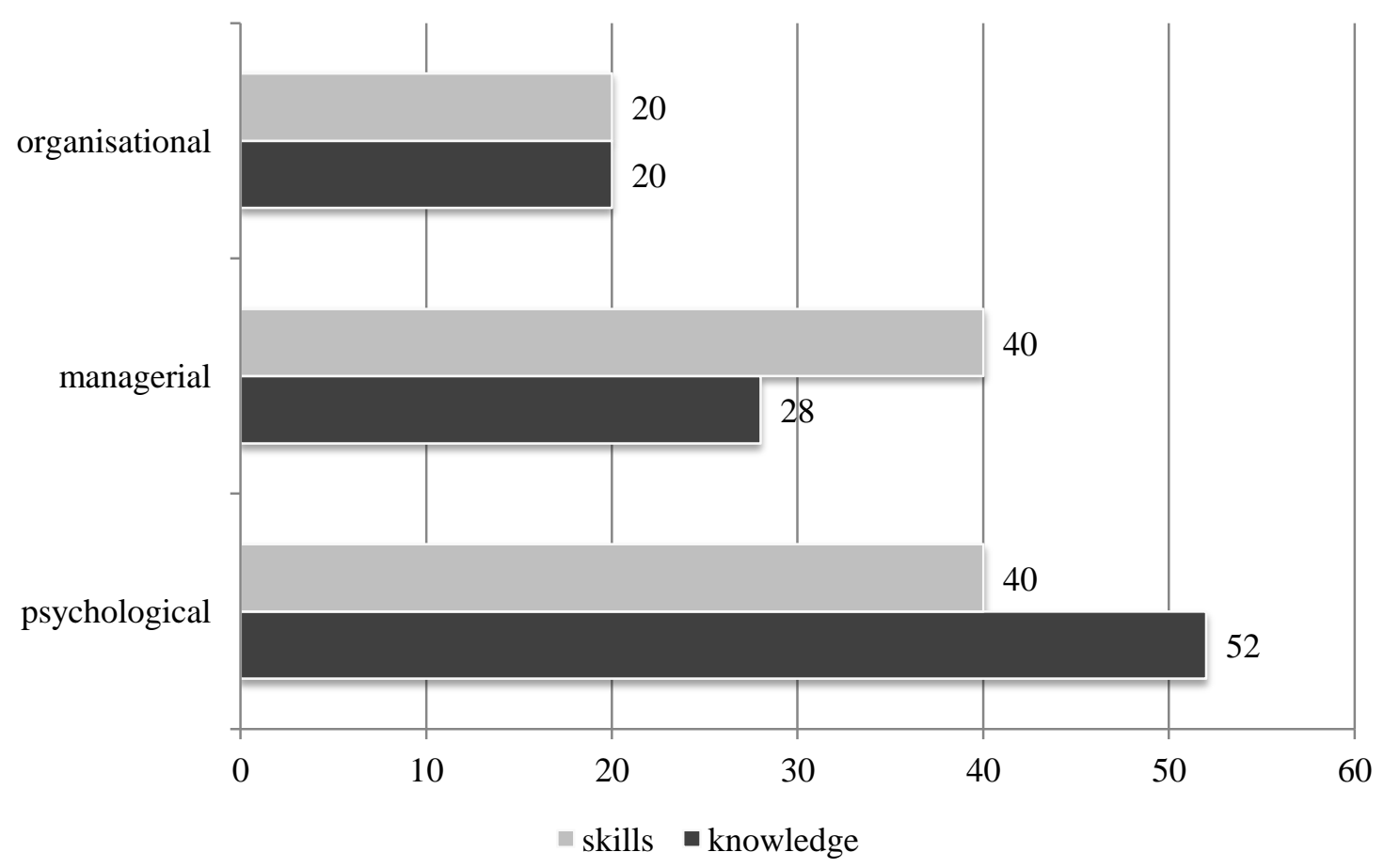

Fig. 6. The main groups of knowledge and practical skills that the participants would like to master (in \% of the total number of respondents)

Source: the author's development

The knowledge and skills indicated by the respondents, which they would like to master during the training, were divided into 3 groups (psychological, managerial and organizational ones). As can be seen on Figure 9, more than half of the participants $(52 \%)$ are interested in obtaining psychological knowledge, and a much smaller percentage of the respondents expect to receive managerial and organizational knowledge (28\% and $20 \%$ respectively). When it comes to practical skills, the number of participants who would like to gain management skills is higher (40\%).

We can conclude that the university managers are interested in gaining psychological knowledge and mastering practical psychological skills. At the same time, a significant part of managers is focused only on managerial and organizational knowledge and skills. In other words, a task of the training to strengthen understanding of the importance of psychological factors in the activities of a university becomes mandatory.

Let us move on to the analysis of the third additional criterion" justifying expectations of the experimental group participants." The results of the survey under this criterion are presented in Table 5. 
Table 5. The extent to which expectations of the experimental group participants regarding the training were met (after the completion of the molding experiment) (in \% of the total number of respondents)

\begin{tabular}{|l|c|}
\hline \multicolumn{1}{|c|}{ The extent to which the expectations have been met } & Number \\
\hline Were fully met & 84,0 \\
\hline Were almost met & 8,0 \\
\hline Were met partially & 8,0 \\
\hline Were not met & 0,0 \\
\hline
\end{tabular}

Source: the author's development

The results of the study show that the expectations that the participants had at the beginning of the training were generally met. The received data show that only $8 \%$ of expectations of the experimental group participants "were partially met" and another $8 \%$ of respondents' "expectations were almost met." The rest of the participants in the experimental group (84\%) indicated that their expectations were "fully met."

When it comes to the analysis of the effectiveness of the training, the experimental group participants generally positively assessed the effectiveness of the training, both in terms of content and form of activities. The proposed questions received a fairly high score (the average value of the sampling as a whole is from 4.56 to 4.9 out of 5 possible points). It should be noted that the survey was conducted anonymously, which indicates a sufficient objectivity of the results.

The performance questionnaire also contained "open-end" questions aimed at assessing the content and form of the training. The analysis of the obtained results showed that the university managers along with the issues that were considered in the course of the training would like to pay attention to other psychological problems of organizations (communication, team building, conflict settlements, etc.) in the future.

Among the additional forms and methods of activities, the group members mentioned business games and analysis of management situations.

Table 6. Evaluation of the effectiveness of the training by the experimental group participants (after completion of the molding experiment)

\begin{tabular}{|l|l|c|}
\hline No & \multicolumn{1}{|c|}{ Questionnaire questions } & $\begin{array}{c}\text { Average value, } \\
\text { points }\end{array}$ \\
\hline 1. By its content: & 4,6 \\
\hline 1.a) & $\begin{array}{l}\text { To what extent does the content of the training correspond to your professional } \\
\text { needs and interests? }\end{array}$ & 4,88 \\
\hline 2. By methods and forms of work: & $\begin{array}{l}\text { How effective were the methods and forms of acitivities during the training } \\
\text { (for finding out key ideas, the content of a particular problem, etc.)? }\end{array}$ \\
\hline 2.a) & $\begin{array}{l}\text { How convenient and comfortable were the methods and forms of activities } \\
\text { during the training (for example, in terms of opportunities to communicate } \\
\text { with other people during completing tasks, places in the space of the room, } \\
\text { your physical and mental condition, etc.)? }\end{array}$ & 4,9 \\
\hline
\end{tabular}

Source: the author's development 
Conducting this training helped university staff (according to the participants' opinions) to create a positive attitude to innovative changes in the current turbulent conditions; to improve the loyalty level to the development of corporate culture at the University; to improve the personal qualities of the participants, which will help increase the level of work efficiency in the conditions of changes; to realize the impact of the importance of organizational culture on the efficiency and quality of the educational process; to form the necessary level of knowledge, skills and abilities to ensure formation of corporate culture of a privately owned higher education institution; to master the skills of analysing the factors that shape corporate culture.

In the end, most of the respondents expressed a wish to continue working on the psychological support for the university's activity.

In other words, in general, the results of the molding experiment confirmed the effectiveness of the training developed by us and proved the possibility of its use for psychological training of managers to develop the organizational culture of a privately owned university.

The results of the molding experiment made it possible to draw the following conclusions:

1. Psychological training of managers with a purpose to develop corporate culture of a privately owned university should be carried out with the help of the training program "Corporate culture of a privately owned university";

2. By its structure, the training program consisted of three training sessions (training session I "Organizational culture as an important factor in ensuring the efficiency and development of the organization"; training session II "Corporate culture of privately owned education institutions"; training session III "Development of corporate culture of privately owned education institutions"). Each of the above, in its turn, contained the introductory and concluding parts and two modules. In addition, the program provided for self-study in a form of homework assignments;

3. The training includes the following active methods and forms of psychological training of the university managers such as mini-lectures; filling in worksheets; "Brainstorming"; group and open-ended discussions; situation analysis; painting; project implementation, psychological workshops, etc.

4. The comparative analysis of the results of diagnostic assessments before and after the molding experiment in the experimental and control groups made by the main indicators of organizational culture of a privately owned university showed the presence of statistically significant differences between the first and second assessments in the experimental group, which manifested themselves in the following, namely:

- Increasing the maturity level of organizational culture under the components of "communication" and "motivation and morality"; 
- The growth of average indicators of the maturity level of the "clan" type of culture;

- Increasing average indicators of the maturity level of "the person culture";

5. The analysis of additional criteria for assessing the effectiveness of the training (evaluation of the need and overall motivation of the experimental group participants to take part in the training; analysis of expectations of the experimental group participants; meeting expectations of the experimental group participants; evaluation of the effectiveness of the training by the experimental group participants (according to the content, forms and methods of activities and the overall score) also showed a positive result of the implementation of the training program for psychological training of managers of a privately owned university for the purposes of development of corporate culture.

The logic of presenting the material proposed by the author is as follows: a theoretical analysis of components of corporate culture, description of their valuebased, behavioural and educational content, experimental confirmation of the role of culture as a core factor in the activity of an education institution, focus on development of key elements of the cultural complex. In other words, all of the above, in fact, shapes a strategy for developing corporate culture of a privately owned higher education institution.

The main points of this Strategy are as follows:

- ensuring the competitiveness of universities by forming staff readiness for changes, including introduction of innovative technologies in the educational process, introduction of new and meaningful update of existing specializations for trainings in accordance with the needs of the labour market, integration of education into the European educational area

- promoting the development of subcultures of corporations formed in separate units and teams, their integration into a new quality that is into the corporate culture of an education institution;

- combination of corporate and cultural values with deontological requirements of professional behaviour of students and teachers. Formation and development of stereotypes among students, in fact, of the corporate behaviour of a future specialist; - gradual adding advantages of the entrepreneurial type of management to the liberal and democratic style of a university management;

- creation conditions for manifestation and realization of individual and creative qualities of university staff and students;

- preservation and increase of acquired material and spiritual corporate values. Directing a set of measures to form organizational and psychological stereotypes of thinking and behaviour of their participants; 
- making strategic and tactical solutions in development of corporate culture human-centralized, meeting personal and individual needs of each subject of corporate culture as a condition for building their potential.

\section{References:}

1. Ball, H. A. (1993), Koncepciya samoaktualizacii lichnosti v gumanisticheskoj psihologi [The concept of self-actualization of personality in humanistic psychology], Kyiv, Ukraine, 32 p.

2. Bondarchuk, O. I. (2003), "Psychological problems of preparation of managers in the system of postgraduate pedagogical education for conflict management in educational organizations", Aktualni problemy psykholohii, part 10, pp. 8-10.

3. Bondarchuk, O. I. (2008), Sotsialno-psykholohichni osnovy osobystisnoho rozvytku kerivnykiv zahalnoosvitnikh navchalnykh zakladiv u profesiinii diialnosti [Socio-psychological bases of personal development of heads of general educational institutions in professional activity], Naukovyi svit, Kyiv, Ukraine, $318 \mathrm{p}$.

4. Biuiul, A. and Tsefel, P. (2002), SPSS: iskusstvo obrabotki informacii. Analiz statisticheskih dannyh $i$ vosstanovlenie skrytyh zakonomernostej [SPSS: the art of information processing. Analysis of statistical data and restoration of hidden patterns], OOO «DyaSoftlup», St. Petersburg, Russia, 608 p.

5. Vynoslavska, O. V. and Malyhina, M. P. (2006), Liudski stosunky [Human relations], Tsentr navchalnoi literatury, Kyiv, Ukraine, 142 p.

6. Chyker, V. A. (2007), Vosemnadtsat prohram trenynhov: rukovodstvo dlia professyonalov [Eighteen training programs: a guide for professionals], Rech, St. Petersburg, Russia, 368 p.

7. Evtykhov, O. V. (2004), Praktyka psykholohycheskoho trenynha [Practice of psychological training], Rech, St. Petersburg, Russia, 256 p.

8. Zavatska, N. Ye. (2014), "An integrative approach to the psychological factors of formation of organizational culture of student youth in the educational environment of the educational institution", Aktualni problemy psykholohii: Orhanizatsiina psykholohiia. Ekonomichna psykholohiia. Sotsialna psykholohiia, p.1, vol. 41, pp. 19-42.

9. Zavatska, N. Ye. Zavatska, N. Ye. and Mitichkina, O. O. (2014), Orhanizatsiina kultura yak skladova psykholohichnoi kultury studentiv vyshchoho navchalnoho zakladu. Psykholohichna kultura: vydy, invarianty, rozvytok [Organizational culture as a component of psychological culture of students of higher educational institution. Psychological culture: types, invariants, development], VVP «Mriia», Sumy, pp. 303327.

10.Kameron, K. Kuynn, R. and Kuynn, R. (2001), Dnahnostyka y yzmerenye orhanyzatsyonnoi kultury [Diagnosis and measurement of organizational culture], Pyter, St. Petersburg, Russia, $320 \mathrm{p}$.

11.Karamushka, L. M. (2005), Tekhnolohii roboty orhanizatsiinykh psykholohiv [Technologies of work of organizational psychologists], Firma «INKOS», Kyiv, Ukraine, 366 p.

12.Karamushka, L. M. Shevchenko, A. M. and Tereshchenko, K. V. (2015), "Organizational culture of educational organizations: essence, structure, functions, types", Aktualni problemy psykholohii: Orhanizatsiina psykholohiia. Ekonomichna psykholohiia. Sotsialna psykholohiia, p. 1, vol. 42, pp. 3-13.

13.Karamushka, L. M. and Malyhina, M. P. (2002), "Types of interactive techniques and features of their application in the training of managers and employees of organizations", Aktualni problemy psykholohii, part 1 , vol. 6 , pp. 275-288.

14.Kolominskyi, N. L. (2000), Psykholohiia menedzhmentu v osviti (sotsialno-psykholohichnyi aspekt) [Psychology of management in education (socio-psychological aspect)], MAUP, Kyiv, Ukraine, 286 p.

15.Ladanov, Y. A. (1997), Psykholohyia upravlenyia rynochnymy strukturamy: Preobrazuiushchee lyderstvo [Psychology of market structure management: Transforming leadership], UTs «Perspektyva», Moscow, Russia, 155 p.

16. Maksymenko, S. D. Karamushka, L. M. Kredentser, O. V. and Fil, O. A. (2005), "Complexes of active methods and forms of psychological preparation of entrepreneurs to increase the efficiency of entrepreneurial activity", Aktualni problemy psykholohii. Sotsialna psykholohiia. Orhanizatsiina psykholohiia. Ekonomichna psykholohiia, part 14, pp. 3-9.

17.Mykhailova, E. V. (2004), Trenynh prezentatsyy tovara [Trening prezentacii tovara], Rech, St. Petersburg, Russia, 64 p.

18. Miliutina, K. L. (2004), Teoriia ta praktyka psykholohichnoho treninhu [Theory and practice of psychological training], MAUP, Kyiv, Ukraine, 192 p. 
19.Nasledov, A. D. (2007), SPSS: Kompyuternyj analiz dannyh v psihologii i socialnyh naukah [SPSS: Computer Data Analysis in Psychology and Social Sciences], Pyter, St. Petersburg, Russia, 416 p.

20.Panok, V. Tytarenko, T. and Chepelieva, N. (2001), Osnovy praktychnoi psykholohii [Fundamentals of practical psychology], Lybid, Kyiv, Ukraine, $536 \mathrm{p}$.

21.Parygina, B. D. (2000), Praktikum po socialno-psihologicheskomu treningu [Workshop on social and psychological training], Mykhailova V.A., St. Petersburg, Russia, pp. 25-47.

22.Karamushky, L. M. (2013), Psykholohichni zasady orhanizatsiinoho rozvytku [Psychological principles of organizational development], Imeks-LTD, Kirovohrad, Ukraine, 206 p.

23. Raduhyn, A. A. and Raduhyn, K. A. (1999), Sotsyolohyia [Sociology], Tsentr, Moscow, Russia, 160 p.

24.Teplova, L. Ye. (2005), "Theory and methodology of managing the development of organizational culture of consumer cooperation", Abstract of Doctor dissertation, Global economy. URL : http://ebib.pp.ua/algoritm-issledovaniya-organizatsionnoy.html.

25.Karamushka, L. M. (2005), Tekhnolohii roboty orhanizatsiinykh psykholohiv [Technologies of organizational psychologists], INKOS, Kyiv, Ukraine, 366 p.

26.Karamushka, L. M. (2008), Tekhnolohiia psykholohichnoi pidhotovky personalu orhanizatsii do roboty $v$ umovakh sotsialno-ekonomichnykh zmin (na materiali osvitnikh orhanizatsii) [Technology of psychological preparation of the personnel of the organizations for work in the conditions of social and economic changes (on a material of the educational organizations)], Naukovyi svit, Kyiv, Ukraine, 366 p.

27.Hlavnyk, O. and Bevz, H. (2005), Tekhnolohiia treninhu [Training technology], Plavnyk, Kyiv, Ukraine, $112 \mathrm{p}$.

28.Fopel, K. (2003), Tekhnolohyia vedenyia trenynha. Teoriia y praktyka [Training technology. Theory and practice], Henezys, Moscow, Russia, 272 p.

29.Hendi, Ch. (2008), Budushchee krupnyh korporacij i melkogo biznesa [The future of large corporations and small businesses], Alpyna Byznes Buks, Moscow, Russia, 204 p.

30.Shein, E. (2001), Orhanyzatsyonnaia kultura y liderstvo [Organizational culture and leadership]. Pyter, St. Petersburg, Russia, 336 p.

31.Yacenko, T. S. (1991), Metody aktivnogo social'no-psihologicheskogo obucheniya [Methods of active socio-psychological training], RUMK, Kyiv, Ukraine, 56 p. 